Irive many gcologists out of the business of making reports on single lots or for individual home-owners. Consultants feel the tinancial risk of law-suits is too great for the modest fees they can charge.

\section{GORDON F.R. (Perth, Western Australia):}

It is quite obvious that geologists have got to get involved in planning and in public life, even into politics. Do you know of any geologists in public life and politics at the present time?

\section{(AMPBLLL I. (in reply):}

Yes, I know of a few. Dr. Harrison ("Jack") Schmitt, the astronaut and first geologist to set foot on the moon, is the Republican candidate for election to the L.S. Senate from the State of New Mexico. Dr. Gordon Gastil, professor of geology at San Diego State Lniversity, was very nearly successful in winning the Democratic primary for a Congressional seat from that area. And a geologist whose name I cannot at the moment recall, was in the Colorado State Legislature and helped guide the bill that reinstituted the Colorado State Geological Survey. I am sure there are other geologists in politics and in public life, but I cannot be specific. I am equally sure there are not enough of them!

* Since completion of this manuscript, Dr. Schmitt has actually been elected to the U.S. Senate.

\title{
Erratu m
}

One major type-setting error in the paper by Ian Campbell "Influence of Geologic Hazards on Legislation in California" published in No. 14 (December 1976) of the IAEG Bulletin demands correction: The length of the San Andreas fault in California is, of course, not "some 100" but "some 1000 kilometers" (p. 201, under "Int roduction", line 9).

\section{Discussion of the paper on "Lahars as Major Geological Hazards" by V.E. Neall}

BEJNAR T.J. (New Mexico Inst. of Mining and Technology, U.S.A.):

Has the following been attempted or thought about: Lahar flows triggered by man to make rimming convenient or tlows smaller?
NLALL V.E. (in reply):

No, not to my knowledge.

\section{Co m m e n t \\ on the paper by D.H. Stapledon "Geological Hazards and Water Storage" (Bulletin of the IAEG, No. 14, 1976, p. 249) sent to the Editor of the Bulletin by P. Londe ${ }^{* *}$}

The "Comment on Londe's theory" (p. 251) contains a statement on which I cannot agree. It reads as follows:

"But if the "pressure induced" change in permeability was as great and significant as suggested by Londe, surely the initial mass permeability would have been high enough to justify completion of the grouting programme".

As a matter of fact the opposite is true: the mechanism of "pressure induced" change in permeability is possible only in rocks of low to very low permeability, where grouting has no effect. This was established by many in situ observations and has been discussed in many papers for the last ten years. It is now accepted by the engineering profession.

Actually I have discussed the point at issue in a number of reports and articles in the past years. Following is a list of publications which is not exhaustive. The works of C. LOUIS (France), J. SHARP (Great Britain), E. GAZIEV (USSR) could be added.

LONDE P. - SABARLY F. (1966) : La distribution des perméabilités dans la fondation des barrages voûtes en fonction du champ de contrainte, ler Congrès International de Mécanique des Roches, Lisbonne, Rapport 8/6.

BERNAIX J. (1966) : Contribution à leétude de la stabilité des appuis de barrages. Etude géotechnique de la roche de Malpasset. Thèse de Doctorat. Ed. Dunod. Paris.

BELLIER J. (1967) : Le barrage de Malpasset, Travaux, Paris, Juillet.

LONDE P. (1967) : Ecoulement de percolation dans les massifs rocheux servant d'appuis aux barrages, La Houills Blanche, $n^{\circ} 1$.

TLR MINASSIAN W. - LONDE P. - SABARLY F (1967) : Comment protéger les barrages voûtes contre la pression de l'eau dans les appuis, IXème Congries des Grands Barrages, Istamboul 1967, Q 32, R 12.

LONDE P. (1968) : Stabilité des massifs rocheux - Application aux barrages, Annales de l'I .T.B.T.P., Paris.

LONDE P. - BERNAIX J. (1969) : Le rôle des essais de mécanique des roches dans l'étude des appuis de harrages. Annales I.T.B.T.P., Juin

LONDE P. (1971) : The flow of water in rock. Cours d'été. Université d'Alberta. Canada, Août 1971.

LONDE P. (1973) : The Mechanics of Rock Slopes and Foundations, Quaterly Journal of Engineering Geology, Vol. 6 , $\mathrm{n}^{\circ} 1$.

LONDE P. (1973) : La mécaniquc les roches et les fondations des grands barrages, Rapport spécial pour la Commission Internationale des Grands Barrages, Paris.

HOEK E. - LONDE P. (1974) : Travaux de Surface. 3ème Congrès International de Mécanique des Roches. Rapport général du Thème 3, Denver, USA.

LONDE P. (1975) : Comment prévoir la déformation des massifs rocheux, Les Annales des Mines, Paris.

GOODMAN R.E. (1976) : Methods of Geological Engineering, West Publishing Company, USA.

** P. Londe, c/o Coyne \& Bellier, 5, rue d'Héliopolis, F-75017 Paris, France. 